\title{
ANTIMICROBIAL SULFONAMIDE DRUGS
}

Ana Tačić*, Vesna Nikolić, Ljubiša Nikolić, Ivan Savić

Faculty of Technology, Leskovac, Serbia

Sulfonamides are the first successfully synthesized antimicrobial drugs. The mechanism of sulfonamides antimicrobial action involves competitive inhibition of folic acid synthesis which prevents the growth and reproduction of microorganisms. Due to this mechanism of action, sulfonamides belong to the group of bacteriostatic agents. Although they have been applied in therapy for more than 70 years, sulfonamides are still the drugs of choice for the treatment of several conditions and diseases. A wider sulfonamides application in the therapy is limited by bacterial resistance and sulfonamides side effects. Antimicrobial sulfonamides and their metabolites are classified as persistent organic pollutants. For sulfonamides degradation and removal from the environment, various techniques can be applied such as different oxidation techniques, including chlorination and advanced oxidation processes, adsorption processes, membrane processes and combined processes.
(REVIEW PAPER)

UDC 547.521:615.33:66.09

Keywords: sulfonamides, antimicrobial activity, mechanism of action, synthesis, side effects, degradation

\section{Introduction}

The discovery of the prontosil (Prontosil rubrum) antimicrobial effect, in the early ' 30 s of the $20^{\text {th }}$ century represents the beginning of the chemiotherapy development [1]. For this discovery, Gerhard Domagk was awarded the Nobel Prize in Medicine in 1939 [2]. Prontosil is an azo-dye with the sulfonamide structure. In the human body, prontosil is metabolized into sulfanilamide under the action of cellular enzymes [3], which is shown schematically in Figure 1.

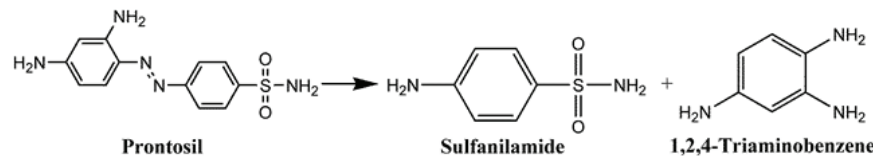

Figure 1. Prontosil conversion into sulfanilamide

Sulfonamides are the first successfully synthesized selectively toxic antimicrobial drugs $[4,5]$. Sulfonamides with the antimicrobial activity represent a large group of drugs which can be classified in different ways. One of the most comprehensive is the sulfonamides classification [6] into:

- Oral sulfonamides which can be absorbed,

- Oral sulfonamides which cannot be absorbed and

- Topical sulfonamides.

According to the duration of action and half-life, absorbable oral sulfonamides can be further divided $[6,7]$ into:

- Short-acting sulfonamides (3-8 h),

- Intermediate-acting sulfonamides (8-18 h) and

- Long-acting sulfonamides (>35 h).
Oral sulfonamides which cannot be absorbed fulfill their role in the gastrointestinal tract, while topical sulfon amides can be used in the treatment of skin and mucous membrane infections and burns.
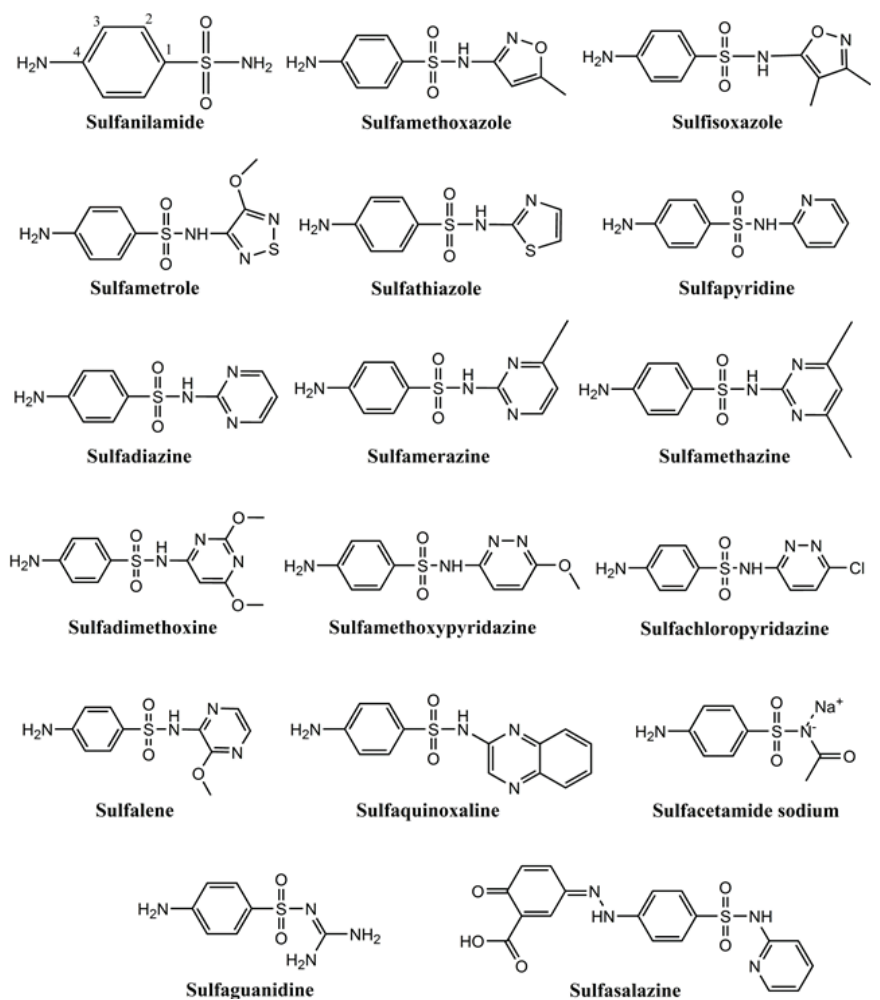

Figure 2. Structures of several sulfonamide antimicrobial drugs

\footnotetext{
* Author address: Ana Tačić, Faculty of Technology,

Bulevar oslobodjenja 124, 16000 Leskovac, Serbia

E-mail: ana.tacic@gmail.com

The manuscript received: April, 07, 2017.

Paper accepted: May, 09, 2017.
} 
The basic sulfonamides structure includes the sulfonamide group and the amino group in the para position of the benzene ring. A large number of sulfonamide derivatives were obtained by substitution of the hydrogen atom on the nitrogen of sulfonamide group $\left(\mathrm{N}_{1}\right)$, whereas a small number of active sulfonamide drugs were obtained by substitution of the hydrogen atom on the nitrogen of aromatic amino group $\left(\mathrm{N}_{4}\right)$. The introduction of various substituents resulted in the products with different physicochemical, pharmacokinetic (a degree of protein binding, metabolism, excretion) and pharmacodynamic properties. The structures of several important representatives of sulfonamide antimicrobial drugs are shown in Figure 2.

\section{Structure-activity relationship}

In the initial phase of the sulfonamides research, a large number of sulfonamide derivatives were synthesized, which made it possible to establish a correlation between specific structural characteristics and the antimicrobial activity of newly created molecules. First of all, a free aromatic $\mathrm{NH}_{2}$ group in the para position, relative to the sulfonamide group, is essential for the activity of sulfonamides [1]. The presence of the additional substituent in the ortho and meta position of the benzene ring reduces the sulfonamide activity. $\mathrm{N}_{1}$-monosubstituted derivatives of sulfanilamide are active compounds whose activity degree increases with the introduction of heteroaromatic substituents. A double substitution in the $\mathrm{N}_{1}$ position leads to inactive compounds. Additionally, the sulfonamide group must be directly attached to the benzene ring. A substitution of the benzene ring by other cyclic system also leads to the reduction or a complete loss of activity.

Table 1. General characteristics of sulfanilamide

\begin{tabular}{ll}
\hline CAS number & $63-74-1$ \\
Molecular mass & 172.2 \\
Molecular formula & $\mathrm{C}_{6} \mathrm{H}_{8} \mathrm{~N}_{2} \mathrm{O}_{2} \mathrm{~S}$ \\
Solubility information & Ethanol, acetone, DMSO \\
Consistency & White to almost white crystalline solid \\
$\lambda_{\text {max }}$ & $255 \mathrm{~nm}, 312 \mathrm{~nm}$ \\
Melting point & $164-165^{\circ} \mathrm{C}$ \\
Density & $1.08 \mathrm{~g} / \mathrm{cm}^{3}$ \\
Water solubility & $7.5 \mathrm{mg} / \mathrm{cm}^{3}$ at $25^{\circ} \mathrm{C}$ \\
pH & $477 \mathrm{mg} / \mathrm{cm}^{3}$ at $100{ }^{\circ} \mathrm{C}$ \\
pK & $5.8-6.1(0.5 \%$ aqueous solution) \\
Stability & 10.4 \\
Storage & Sensitive to light \\
Classification & $0-6{ }^{\circ} \mathrm{C} ;$ Protect from light. \\
\hline
\end{tabular}

The first sulfonamide - sulfanilamide

Sulfanilamide (4-aminobenzenesulfonamide) is the basic representative of sulfonamide antimicrobial drugs. The clinical significance of sulfanilamide is not large because it is very rarely applied in therapy nowadays due to the synthesis of more efficient products. However, sulfanilamide represents the fundamental structural and functional unit of the entire class of antimicrobial sulfonamides. The structural formula of sulfanilamide is given in Figure 2, while its physical and chemical characteristics are listed in Table 1.

Sulfanilamide is a stable substance under normal temperature and pressure conditions. It is sensitive to light and incompatible with strong oxidizing agents [8]. The solubility of sulfanilamide in ethanol $\left(\sim 27 \mathrm{mg} / \mathrm{cm}^{3}\right)$ and acetone $\left(\sim 200 \mathrm{mg} / \mathrm{cm}^{3}\right)$ [8] is greater than in water. Sulfanilamide is a weak acid $(\mathrm{pKa}=10.4)$ due to the strong electron attractive effect of $-\mathrm{SO}_{2}$ substituent and resonance stabilization of the resulting anion [9]. Sulfanilamide ionization is given in Figure 3.

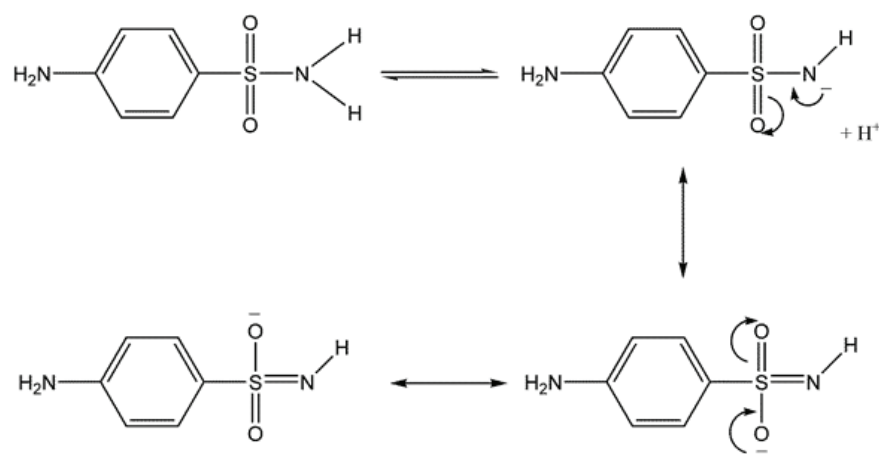

Figure 3. Schematic representation of sulfanilamide ionization

\section{Sulfonamide synthesis}

The most common method of sulfonamide synthesis involves a reaction of corresponding aliphatic or aromatic sulfonyl chloride with ammonia or an adequate amine. This synthesis method represents the simplest and direct pathway to obtain sulfonamides, wherein the sulfonamide yield is high $[10,11]$. This will be explained in detail in the case of sulfanilamide.

The initial compound for a multistep sulfanilamide synthesis is nitrobenzene [12]. Nitrobenzene can be reduced using tin, as a reducing agent, and hydrochloric acid to give the anilinium ion, which can be converted to aniline using sodium hydroxide. Acetanilide, a compound insoluble in water, can be derived from aniline by the reaction of acetylation in the aqueous medium. The next step in the synthesis is the reaction of the electrophilic aromatic substitution in which acetanilide reacts with chlorosulfonic acid to give the intermediate 4-acetamidobenzenesulfonyl chloride. The formed intermediate, in the presence of ammonia, gives 4-acetamidobenzene sulfonamide. The acetamide group causes the substitution almost completely in the para position [13]. In the final step of the synthesis, the protecting acetamide group undergoes to hydrolysis in acidic medium and forms 4-aminobenzenesulfonamide, sulfanilamide. The synthesis of sulfanilamide is presented in Figure 4. 
<smiles>O=[N+]([O-])c1ccccc1</smiles>
$\underset{2 .}{\stackrel{\text { 1. } \mathrm{On} / \mathrm{HCl}}{\longrightarrow}}$ Nitrobenzene<smiles>[CH2]C(=O)NC</smiles><smiles>CCNc1ccc(S(=O)(=O)Cl)cc1</smiles>
chloride<smiles>Nc1ccccc1</smiles>

$\underset{\mathrm{CH}_{3} \mathrm{COONa}}{\stackrel{\left(\mathrm{CH}_{3} \mathrm{COO}\right)_{2} \mathrm{O}}{\longrightarrow}}$ Aniline
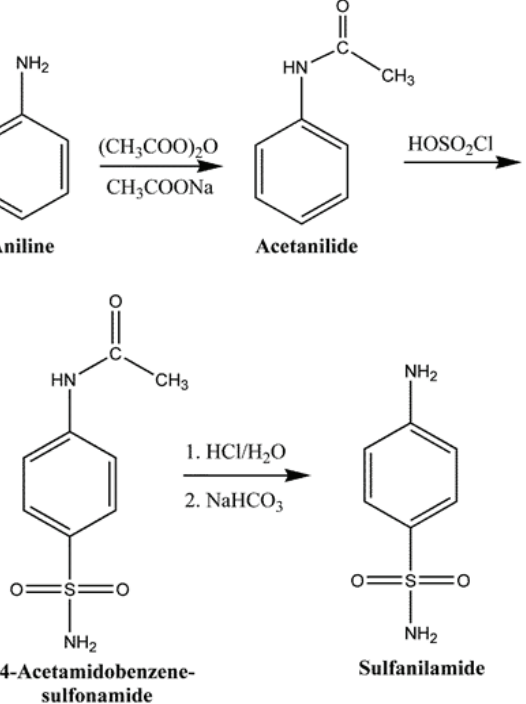

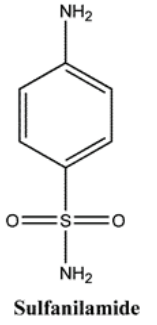

Sulfanilamide
Figure 4. Schematic representation of the sulfanilamide synthesis

\section{Antimicrobial activity}

Sulfonamides are antimicrobial drugs with a broad spectrum of action, effective against Gram-positive and certain Gram-negative bacteria, such as intestinal bacteria Escherichia coli, Klebsiella, Salmonella, Shigella and Enterobacter species [6]. Sulfonamides show a good activity against $E$. coli, moderate against Proteus mirabilis and Enterobacter species and weak against Klebsiella, but they show no inhibitory activity against Pseudomonas aeruginosa and Serratia species. They are effective against species of Chlamydia genus. Sulfonamides are also effective against fungi (Pneumocystis carinii) and protozoa (Toxoplasma gondii). Sulfonamides differ in potency, but not in the spectrum of the antimicrobial activity $[14,15]$.

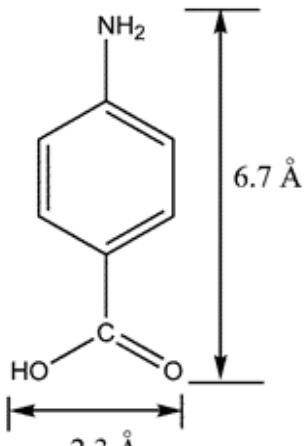

$2.3 \AA$

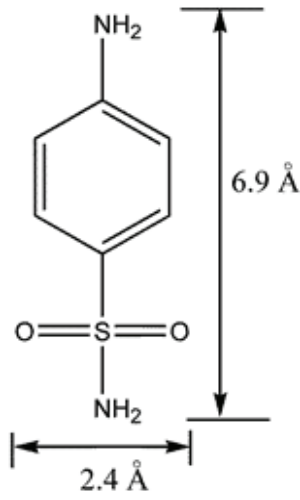

Sulfanilamide
p-Aminobenzoic acid (PABA)

Figure 5. Structure similarity of sulfanilamide and $p$-aminobenzoic acid

Mechanism of sulfonamide action

Sulfonamides are competitive antagonists of $p$-aminobenzoic acid (PABA), the compound essential for the synthesis of folic acid, and thus for the bacterial growth and reproduction. Sulfonamides reversibly block the synthesis of folic acid, thus having the bacteriostatic effect $[6,16]$.
The basis of the inhibitory effect is the similarity between sulfonamide and PABA structures, which is given in the example of sulfanilamide (Figure 5).

Normally, the first step of folic acid synthesis is the reaction of PABA and pteridine [17] in the presence of enzyme dihydropteroate synthase. During this step, dihydro pteroic acid is produced. The formed intermediate reacts with glutamic acid producing dihydrofolic acid under the activity of enzyme dihydrofolate synthase. In the presence of enzyme dihydrofolate reductase, dihydrofolic acid is then converted into tetrahydrofolic acid, which is used by bacteria in the synthesis of methionine, purine and pyrimidine bases [6,14]. However, in the sulfonamides presence, enzyme dihydropteroate synthase binds to these structural PABA analogs, which prevents the folic acid synthesis and DNA synthesis in the bottom line. Folic acid synthesis and sulfonamides site of folic acid metabolism inhibition are presented schematically in Figure 6.
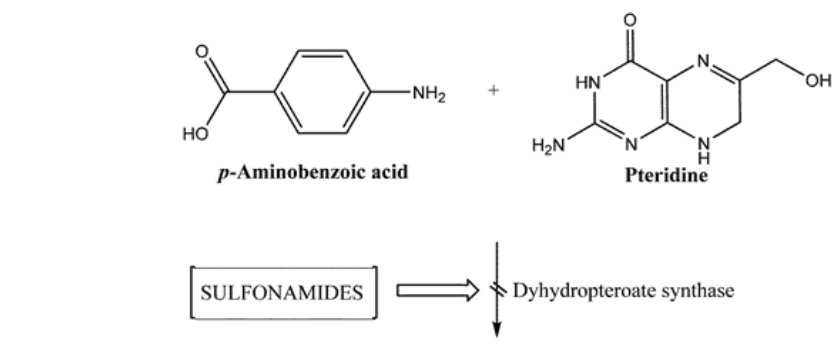<smiles>Nc1nc(=O)c2c([nH]1)NC(CNc1ccc(C(=O)O)cc1)=NC2</smiles><smiles>Nc1nc(=O)c2c([nH]1)NCC(CNc1ccc(C(=O)N[C@@H](CCC(=O)O)C(=O)O)cc1)N2</smiles>

Figure 6. Folic acid synthesis and sulfonamides site of action 
Table 2. Commercial sulfonamide drugs available in RS and USA market

\begin{tabular}{|c|c|c|c|}
\hline $\begin{array}{l}\text { Sulfonamide } \\
\text { Active Substance }\end{array}$ & Dosage Form & Commercial Drug & Manufacturer \\
\hline \multirow[t]{14}{*}{$\begin{array}{l}\text { Sulfamethoxazole- } \\
\text { trimethoprim }\end{array}$} & \multirow[t]{6}{*}{$\begin{array}{l}\text { Oral tablets, } 400 \mathrm{mg}+ \\
80 \mathrm{mg}\end{array}$} & Septra & $\begin{array}{l}\text { Monarch Pharmaceuticals Inc. } \\
\text { (a subsidiary of King } \\
\text { Pharmaceuticals Inc.) }\end{array}$ \\
\hline & & Bactrim & $\begin{array}{l}\text { Sun Pharmaceutical Industries } \\
\text { Ltd. }\end{array}$ \\
\hline & & $\begin{array}{l}\text { Sulfamethoxazole and } \\
\text { trimethoprim single strength }\end{array}$ & Teva Pharmaceuticals \\
\hline & & Bactrim & Galenika AD Beograd \\
\hline & & Esbesul & Bosnalijek D.D. \\
\hline & & $\begin{array}{l}\text { Sulfamethoxazole and } \\
\text { trimethoprim }\end{array}$ & $\begin{array}{l}\text { Vista Pharmaceuticals Inc.; } \\
\text { Amneal Pharmaceuticals NY; } \\
\text { Chartwell Pharmaceuticals } \\
\text { LLC; } \\
\text { Aurobindo Pharma Ltd.; } \\
\text { Glenmark Pharmaceuticals } \\
\text { Ltd. }\end{array}$ \\
\hline & \multirow[t]{3}{*}{$\begin{array}{l}\text { Oral tablets, } 800 \mathrm{mg}+ \\
160 \mathrm{mg}\end{array}$} & $\begin{array}{l}\text { Septra DS } \\
\text { Bactrim DS }\end{array}$ & $\begin{array}{l}\text { Monarch Pharmaceuticals Inc. } \\
\text { Sun Pharmaceutical Industries } \\
\text { Ltd. }\end{array}$ \\
\hline & & $\begin{array}{l}\text { Sulfamethoxazole and } \\
\text { trimethoprim double } \\
\text { strength }\end{array}$ & Teva Pharmaceuticals \\
\hline & & $\begin{array}{l}\text { Sulfamethoxazole and } \\
\text { trimethoprim }\end{array}$ & $\begin{array}{l}\text { Vista Pharmaceuticals Inc.; } \\
\text { Amneal Pharmaceuticals NY; } \\
\text { Chartwell Pharmaceuticals } \\
\text { LLC; } \\
\text { Aurobindo Pharma Ltd.; } \\
\text { Glenmark Pharmaceuticals } \\
\text { Ltd. }\end{array}$ \\
\hline & \multirow{3}{*}{$\begin{array}{l}\text { Syrup, } \\
200 \mathrm{mg} / 5 \mathrm{~mL}+40 \mathrm{mg} / 5 \mathrm{~mL} \\
\text { Oral suspension, } 200 \\
\mathrm{mg} / 5 \mathrm{ml} ; 40 \mathrm{mg} / 5 \mathrm{ml}\end{array}$} & Bactrim & $\begin{array}{l}\text { Galenika AD Beograd } \\
\text { F. Hoffmann-La Roshe LTD }\end{array}$ \\
\hline & & Sulfatrim Pediatric & STI Pharma, LLC. \\
\hline & & $\begin{array}{l}\text { Sulfamethoxazole and } \\
\text { trimethoprim }\end{array}$ & $\begin{array}{l}\text { Hi Tech Pharmacal Co. Inc.; } \\
\text { Vintage Pharmaceuticals; } \\
\text { Aurobindo Pharma Ltd. }\end{array}$ \\
\hline & $\begin{array}{l}\text { Injection, } 80 \mathrm{mg} / \mathrm{ml}+ \\
16 \mathrm{mg} / \mathrm{ml}\end{array}$ & $\begin{array}{l}\text { Sulfamethoxazole and } \\
\text { trimethoprim }\end{array}$ & Teva Pharmaceuticals \\
\hline & $\begin{array}{l}\text { Concentrate for } \\
\text { solution for infusion, } \\
400 \mathrm{mg} / 5 \mathrm{~mL}+80 \mathrm{mg} / 5 \mathrm{~mL}\end{array}$ & Bactrim Roshe ${ }^{\mathrm{TM}}$ & F. Hoffmann-La Roshe LTD \\
\hline \multirow[t]{6}{*}{ Sulfasalazine } & \multirow[t]{2}{*}{$\begin{array}{l}\text { Oral tablets, delayed } \\
\text { release, } 500 \mathrm{mg}\end{array}$} & Sulfasalazine & $\begin{array}{l}\text { Vintage Pharmaceuticals Inc. } \\
\text { (a subsidiary of Generics } \\
\text { International Inc.) }\end{array}$ \\
\hline & & Azulfidine EN-tabs & $\begin{array}{l}\text { Pharmacia and Úpjohn } \\
\text { Company LLC (a subsidiary of } \\
\text { Pfizer Inc.) }\end{array}$ \\
\hline & $\begin{array}{l}\text { Gastro-resistant } \\
\text { tablets, } 500 \mathrm{mg}\end{array}$ & Salazopyrin EN & Kemwell AB RS \\
\hline & \multirow[t]{2}{*}{ Oral tablets, $500 \mathrm{mg}$} & Sulfasalazine & $\begin{array}{l}\text { Vintage Pharmaceuticals Inc. } \\
\text { Watson Laboratories Inc. (a } \\
\text { subsidiary of Allergan) }\end{array}$ \\
\hline & & Azulfidine & $\begin{array}{l}\text { Pharmacia and Upjohn } \\
\text { Company LLC }\end{array}$ \\
\hline & $\begin{array}{l}\text { Oral suspension }(250 \\
\mathrm{mg} / 5 \mathrm{ml})\end{array}$ & Azulfidine & $\begin{array}{l}\text { Pharmacia and Upjohn } \\
\text { Company LLC }\end{array}$ \\
\hline $\begin{array}{l}\text { Erythromycin } \\
\text { ethylsuccinate; } \\
\text { sulfisoxazole } \\
\text { acetyl }\end{array}$ & $\begin{array}{l}\text { Oral granules, } \\
\text { Eq. } 200 \mathrm{mg} \text { base } / 5 \mathrm{ml} \text {; } \\
\text { eq. } 600 \mathrm{mg} \text { base } / 5 \mathrm{ml}\end{array}$ & $\begin{array}{l}\text { Erythromycin } \\
\text { ethylsuccinate and } \\
\text { sulfisoxazole acetyl }\end{array}$ & $\begin{array}{l}\text { Barr Pharmaceuticals Inc. (a } \\
\text { subsidiary of Teva } \\
\text { Pharmaceuticals) }\end{array}$ \\
\hline \multirow{6}{*}{$\begin{array}{l}\text { Sulfanilamide } \\
\text { Sulfacetamide } \\
\text { sodium }\end{array}$} & \multirow{3}{*}{$\begin{array}{l}\text { Vaginal cream } \\
\text { Ophthalmic solution, } \\
10 \%\end{array}$} & $A \vee C$ & Meda Pharmaceuticals Inc. \\
\hline & & Bleph-10 & Allergan \\
\hline & & Sulfacetamide sodium & $\begin{array}{l}\text { Bausch\& Lomb Inc.; } \\
\text { Akorn Inc.; } \\
\text { Alcon (a subsidiary of } \\
\text { Novartis) }\end{array}$ \\
\hline & $\begin{array}{l}\text { Ophthalmic ointment, } \\
10 \%\end{array}$ & Sulfacetamide sodium & Perrigo Co. Tennessee \\
\hline & \multirow[t]{2}{*}{ Topical lotion, $10 \%$} & Klaron & $\begin{array}{l}\text { Valeant Pharmaceuticals } \\
\text { International, Inc. }\end{array}$ \\
\hline & & Sulfacetamide sodium & $\begin{array}{l}\text { Fougera Pharmaceuticals Inc.; } \\
\text { Perrigo Co. Tennessee; } \\
\text { Taro Pharmaceutical } \\
\text { Industries Ltd. }\end{array}$ \\
\hline \multirow{2}{*}{$\begin{array}{l}\text { Prednisolone } \\
\text { acetate; } \\
\text { sulfacetamide } \\
\text { sodium }\end{array}$} & \multirow{2}{*}{$\begin{array}{l}\text { Ophthalmic } \\
\text { suspension, } \\
0.2 \% ; 10 \% \\
\text { Ophthalmic ointment, } \\
0.2 \% ; 10 \%\end{array}$} & Blephamide & Allergan \\
\hline & & Blephamide S.O.P. & Allergan \\
\hline \multirow{7}{*}{$\begin{array}{l}\text { Sulfacetamide } \\
\text { sodium and } \\
\text { prednisolone } \\
\text { sodium phosphate } \\
\text { Sulfadiazine } \\
\text { Silver sulfadiazine }\end{array}$} & $\begin{array}{l}\text { Ophthalmic solution, } \\
\text { eq. } 0.23 \% \text { phosphate; } \\
10 \%\end{array}$ & $\begin{array}{l}\text { Sulfacetamide sodium; } \\
\text { prednisolone sodium } \\
\text { phosphate }\end{array}$ & $\begin{array}{l}\text { Alcon; } \\
\text { Bausch \& Lomb Inc. }\end{array}$ \\
\hline & \multirow{6}{*}{$\begin{array}{l}\text { Oral tablets, } 500 \mathrm{mg} \\
\text { Topical cream, } 1 \%\end{array}$} & Sulfadiazine & Sandoz Pharmaceuticals d.d. \\
\hline & & Silvadene & $\begin{array}{l}\text { King Pharmaceuticals Inc. (a } \\
\text { subsidiary of Pfizer Inc.) }\end{array}$ \\
\hline & & SSD & Dr Reddy's LA \\
\hline & & SSD AF & Dr Reddy's LA \\
\hline & & Thermazene & The Pharma Network LLC. \\
\hline & & Sanaderm & Zdravlje AD Leskovac \\
\hline
\end{tabular}




\section{Sulfonamides application in therapy}

Nowadays, sulfonamides are most frequently used in the treatment of urinary tract infections caused by susceptible strains of bacteria. Acute, uncomplicated urinary tract infections caused by $E$. coli and other bacteria can be adequately treated with sulfamethoxazole (SMX) and trimethoprim (TMP) combination [18]. However, recurrent urinary tract infections are usually caused by pathogens resistant to sulfonamides. For this reason, sulfonamides cannot be applied in the therapy. Both drugs exhibit a bacteriostatic effect when they are administered separately. Unlike that, their combination (SMX/TMP) exhibits a bactericidal effect.

SMX is an antimicrobial drug which is used in the treatment of urinary tract infections [19], bronchitis [20] and prostatitis [21]. SMX/TMP combination can be used in the therapy of encephalomyelitis [22], and together with azithromycin, in the treatment of ocular toxoplasmosis $[23,24]$. Vena et al. [25] demonstrated that the combination of a high dose of daptomycin with SMX/TMP is a reasonable option for the treatment of meningitis caused by multidrug-resistant Staphylococcus epidermidis. SMX/TMP combination remains the most effective antimicrobial drug in the therapy of the infection caused by less common non-fermenters, except Acinetobacter baumannii. Against these microorganisms, sulfametrole (SML) and sulfametrole/trimethoprim (SML/TMP) combination are generally effective as SMX and SMX/TMP combination. Additionally, SML and SML/TMP combination do not exceed the Enterobacteridaceae resistance to SMX and SMX/TMP combination [26].

Sulfadiazine (SDZ) is used in the prophylaxis and the treatment of infections caused by Pneumocystis carinii, particularly in patients with AIDS and other immunocompromised patients, as well as in the case of toxoplasmosis caused by Toxoplasma gondii [27]. The combination of SDZ with pyrimethamine is used in the treatment of ocular toxoplasmosis, although SMX/TMP combination represents an efficient alternative [28]. SDZ and sulfisoxazole (SXZ) play an important role in the prophylaxis of streptococcal infections in patients with rheumatic fever allergic to penicillin [29].

Sulfonamides which cannot be absorbed (phthalylsulfathiazole, succinylsulfathiazole, salicylazosulfapyridine) are used in the therapy of intestinal infections, ulcerative colitis and enteritis [6].

Topical sulfonamides can be applied in the form of solutions or ointments in the conjunctivitis therapy, as well as an additional drug in the treatment of trachoma [3]. Sulfacetamide sodium (SAM) can be used topically in the treatment of eye infections, such as bacterial conjunctivitis [30]. Sensoy et al. [31] have developed the bio-adhesive, polymeric microspheres with SAM in order to increase the drug retention time on the eye surface, resulting in a more effective treatment of ocular keratitis caused by Staphylococcus aureus and P. aeruginosa in a rabbit model. Emollient foam, which contains $10 \%$ of SAM and $5 \%$ of sulfur, is used in the treatment of acne vulgaris [32] and papulopustular rosacea [33].

Topical sulfonamides are applied in the infection prevention in patients with burns. Silver sulfadiazine can be used in the burns treatment in the form of $1 \%$ hydrophilic cream [34], and shows good activity against Gram negative bacteria, particularly against $P$. aeruginosa which often colonizes burned tissue.

A broader sulfonamides application in the therapy is limited due to bacterial resistance and sulfonamides side effects. Additionally, since sulfonamide introduction in the therapy more than 70 years ago, a great number of antimicrobial agents that suppressed sulfonamides application have been isolated and synthesized. However, sulfonamides still represent the drugs of first choice for the treatment of some conditions and diseases [35].

Sulfonamides drugs available on the market of the Republic of Serbia (RS) and the United States of America (USA), according to Medicines and Medical Devices Agency of Serbia and Food and Drug Administration, are presented in Table 2.

\section{Pharmacokinetics of sulfonamides}

With the exception of certain topical and parenteral [36] sulfonamide preparations, the majority of sulfonamide drugs are administered orally. It is the reason why their absorption into systemic circulation is essential for the expression of their pharmacological effects in the target tissues and organs. After oral administration, sulfonamides are well absorbed from the digestive tract [6]. The exceptions are sulfaguanidine (SGV) [37] and sulfasalazine (SLZ) [38] which practically cannot be absorbed. For this reason, they are used in the intestinal infections treatment. The maximum concentration in blood can be achieved in the range of $0.5-3 \mathrm{~h}$ after oral administration $[6,39]$, depending on the sulfonamide structure. After absorption, sulfonamides are distributed in all tissues and body fluids, including cerebrospinal fluid and fetal tissue. Sulfonamide distribution in the body depends on its physical and chemical characteristics, the binding affinity to plasma proteins and human organism condition [40]. The degree of binding to plasma proteins can vary greatly between different sulfonamides. Thus, the binding degree of sulfanilamide and SDZ is $20-30 \%$ [6], for sulfalene (SFL), sulfamerazine (SMZ) and sulfathiazole (STZ) it is $70-75 \%$ and even $98 \%$ for sulfadimethoxine (SDM) [36].

Metabolism of sulfonamides is species-dependent [36]. In the turtles [41] and monkeys [27], the main metabolic pathway is oxidation, wherein one or two hydroxyl groups are introduced in the position 4, 5 or 6 of sulfonamides moiety to form corresponding monohydroxy or dihydroxy metabolites. These metabolites retain a part (2.5-39.5\%) of antimicrobial activity [42] of the parental sulfonamides and excrete in the urine unchanged or after conjugation with glucuronic acid or sulfate [38].

In humans, metabolic transformation of sulfonamides takes place mainly in the liver by acetylation of amino group. The resulting $\mathrm{N}$-acetyl metabolites are inactive 
and can be excreted in the urine together with the unchanged sulfonamides [40]. However, in humans the cytochrome P450 catalyzed $\mathrm{N}$-oxidation is also possible, which produces reactive hydroxylamine metabolites [43].

This metabolic reaction is particularly present in slow acetylators with deficiency of polymorphic enzyme $\mathrm{N}$ acetyltransferase. Once formed, hydroxylamino metabolites can undergo auto-oxidation to the corresponding nitrozo intermediates. Nitrozo metabolites are unstable in body fluids and can be reduced using glutathione and excreted. However, when the capacity for conjugation with glutathione is exceeded, the reactive metabolites show a direct cytotoxic activity or can be bound to proteins and participate in the immune reactions.

Most of sulfonamides can be rapidly excreted through kidneys. The exceptions are depot sulfonamides which can be reabsorbed in the renal tubules and very slowly excreted from the body [6]. The rate and mode of sulfonamide excretion depend on the applied compound, administered dose, treated species and route of administration [44]. For example, SDZ can be eliminated from the body unchanged in the amount of $50 \%$, as well as in the form of acetyl and glucuronide conjugates (50\%) through urine and feces.

\section{Sulfonamides side effects}

Sulfonamides cause side effects in $4-6 \%$ of the treated patients from general population and even 50-60\% of patients with HIV infection $[45,46]$. Hypersensitivity is the most common adverse reaction to sulfonamides and it is often referred to as 'sulfa allergy'. Reported adverse effects include fever (in 1-2\% of patients), anaphylactic shock, serum sickness, systemic vasculitis, pneumonia, hepatitis, myocarditis, interstitial nephritis, blood dyscrasia such as hemolytic anemia, neutropenia, thrombocytopenia and pancytopenia, and different skin reactions, including severe reactions such as Steven-Johnson syndrome and toxic epidermal necrolysis [14,45,47]. In some patients, urinary tract disorder occurs as a result of metabolite precipitation (acetylated sulfonamides), especially in the case of acidic urine. This can be avoided by using soluble sulfonamides and by maintaining the alkaline reaction of urine $[6,14]$.

Sulfonamides cause side effects via different mechanisms. In some cases, the mechanism of a toxic sulfonamides effect is known. For instance, deficiency of the enzyme glucose-6-phosphate dehydrogenase leads to hemolytic anemia in patients treated with sulfonamides [4]. However, the mechanism of adverse reactions to sulfonamides is not precisely determined in most cases. It is believed that the mechanism of toxic sulfonamide effects represents the combination of a direct toxic effect of sulfonamide metabolites, formed by $N$-oxidation under the effect of cytochrome P450 enzymes and the immune mechanism involving the specific sulfonamide allergen recognition by the immune system [48]. Risk factors, including slow acetylator phenotype [49], a high drug dose, severe immunodeficiency and glutathione deficiency af- fect the development of hypersensitivity to sulfonamides, especially in HIV-positive patients.

It is considered that individuals who show hypersensitivity reactions to antimicrobial sulfonamides will exhibit similar adverse effects to other sulfonamide classes; this is referred to as cross-reactivity. As the number of drugs with the sulfonamide functional group on the market is large, the issue of cross-reactivity to sulfonamides is of great clinical importance $[43,46]$. For that reason, a significant number of clinical studies of different extent, which considered the issue of cross-reactivity, were conducted. Shapiro et al. [50] have estimated the incidence of cross-reactivity to celecoxib in 28 patients with the history of allergies to sulfonamides. They have concluded that the risk of cross-reactivity in these patients is low. In a study conducted by Strom et al. [51] out of 969 patients who developed documented allergic reaction to antimicrobial sulfonamides, even $9.9 \%$ had an allergic reaction to non-antimicrobial sulfonamide drugs. Out of 19,257 subjects from the control group, which did not develop an adverse reaction to sulfonamide antimicrobials, only $1.6 \%$ developed the reaction to non-antimicrobial sulfonamide drugs. This indicates to a certain degree of cross-reactivity between different classes of sulfonamide drugs [46,51]. Although hypersensitivity to sulfonamide antimicrobial drugs results in the increased risk for allergic reaction to other sulfonamide classes, the results of other studies imply that this risk is not limited to sulfonamides only. Specifically, patients with the history of hypersensitivity to antimicrobial sulfonamides have a higher risk of hypersensitivity reactions to penicillins, which are not structurally similar to sulfonamides [51]. Based on this, it can be concluded that there is a link between hypersensitivity to antimicrobial sulfonamides and other sulfonamide drugs. However, this is the consequence of predisposition to allergic reactions rather than the crossreactivity $[43,51]$.

Reactive hydroxylamino metabolites, which are considered to be responsible for adverse reactions to antimicrobial sulfonamides, cannot be formed during biotransformation of thiazide diuretics, loop diuretics, sulfonylurea derivatives and other non-antimicrobial sulfonamides, due to which the probability of the crossreactivity development is low $[52,53]$.

Sulfonamides compete with bilirubin for binding the plasma proteins, which may lead to the development of kernicterus in newborns. Therefore, sulfonamides should not be applied in newborns and during last two months of pregnancy. Additionally, sulfonamides may potentiate the effect of some drugs such as anticoagulants, hypoglycemic sulfonylurea derivatives and hydantoin anticonvulsants, which should be considered during the simultaneous application of these drugs [14].

Nowadays, there are a few methods for diagnosis of adverse reactions to sulfonamides, because the exact mechanism of the side effects development is unknown, making it difficult to select the appropriate diagnostic test. Currently, diagnosing allergies to drugs, including 
sulfonamides, is based on taking a detailed history and on physical examination. In addition, specific in vivo and in vitro tests can be useful in determining hypersensitivity to a drug, such as skin testing with SMX-conjugate or the native drug (immediate hypersensitivity reactions only), lymphocyte transformation assays, lymphocyte cytotoxicity assays and assays for detecting antibodies to endoplasmic reticulum luminal proteins (for delayedonset hypersensitivity-type reactions) [45].

\section{Bacterial resistance to sulfonamides}

The treatment of bacterial infections can be significantly complicated by the ability of bacteria to develop resistance to antimicrobial drugs. Bacteria may be inherently resistant to antimicrobial drugs (inherent resistance) or may acquire resistance by de novo mutation or by receiving genetic material from resistant bacteria (acquired resistance). Acquired resistance can be manifested as the production of enzymes which degrade the antibacterial drug, the expression of the efflux system which prevents the drug to reach the target site of action within the cell, the modification of the drug action target site, or the development of the alternative metabolic pathway to which the drug has no effect [54].

Bacterial resistance to sulfonamides can be explained in several ways. It is possible that the chromosomal mutation in folP gene of $E$. coli causes the substitution of the phenylalanine residue in position 28 by the isoleucine residue, which results in lower affinity of enzyme to sulfonamides [55]. Similar mutations can be responsible for the resistance of Streptococcus pneumoniae, Campylobacter jejuni, Haemophilus influenzae, Streptococcus pyogenes and Streptococcus mutans [56]. In the case of Neisseria meningitidis, the differences in folP gene between resistant and sensitive strains are almost $10 \%$, which indicates that resistance is caused by recombination, rather than point mutations [55,57]. Plasmid-mediated resistance to sulfonamides is caused by drug-resistant dihydropteroate synthase coded by sul1 and sul2 genes. Sul1 gene is linked to other genes of resistance in class 1 integrons [58], while sul2 is usually located on small plasmids. Livermore et al. [26] have confirmed that sul1 and sul2 genes are responsible for resistance of $E$. coli to SMX and SML. The frequency of these genes in Gram-negative clinical isolates resistant to sulfonamides is approximately similar [59]. The origin of these genes is unknown.

Bacterial resistance to sulfonamides and other antimicrobial drugs represents a major problem. More frequent appearance of multiresistant strains of Klebsiella pneumoniae, Staphylococcus, Enterococcus and Pseudomonas species in health institutions leads to the treatment failure, which can cause complications, especially in older people, children and immunocompromised patients. In order to overcome the issue of bacterial resistance to sulfonamides, the combinations of certain sulfonamides drugs such as SDZ, SMZ and STZ (Triple sulfas) can be used. The combinations of sulfonamides drugs contribute to overcoming the microbial resistance.

\section{Sulfonamides degradation and removal from the environment}

The application of sulfonamides and other antimicrobial drugs in therapy leads to their continuous introduction into the environment and spreading and maintaining the bacterial resistance. For that reason, the removal of antimicrobial drugs from the environment represents a serious issue from the environmental protection aspect, and more importantly, from the aspect of microorganisms resistance prevention.

Antimicrobial sulfonamides and their metabolites are classified as persistent organic pollutants, due to their resistance to biodegradation [60]. Conventional purification techniques, such as filtration, coagulation, flocculation and sedimentation are not sufficiently effective in the case of sulfonamides and their metabolites. Namely, only $20-30 \%$ of present antimicrobial drugs, including sulfonamides, can be removed by using conventional techniques [61]. Due to the low efficiency of these techniques, new alternative techniques have been developed. First of all, there are a variety of oxidation methods (chlorination and advanced oxidation processes (AOPs)), then adsorption processes, membrane processes and combined processes.

\section{Chlorination}

Chlorine and hypochlorite are often used oxidizing agents, due to their low cost. They are usually applied as a part of post-treatment. Also, they can be applied before a biological treatment in order to oxidize antimicrobial agents to easily biodegradable and less toxic compounds. Adams et al. [62] have studied the sulfonamides, trimethoprim and carbadox degradation using chlorine. It has been shown that chlorine oxidation represents a fast and efficient method for the removal of these antimicrobial drugs (>90\%). However, chlorination leads to the formation of chlorinated intermediates, which can be carcinogenic and more toxic than the initial compounds. In order to prevent the formation of dangerous halogenated compounds, new techniques have been developed, primarily AOPs.

\section{Advanced oxidation processes}

AOPs are oxidative techniques based on the formation and effect of highly reactive free radicals, such as hydroxyl $\left({ }^{*} \mathrm{OH}\right)$ radicals, which are less selective compared to other oxidizing agents [61]. Free radicals can be formed from ozone or hydrogen peroxide in the presence of metal or semiconductor catalysts and/or UV radiation. Under the effect of free radicals, organic compounds can be oxidized to less toxic intermediates, and ultimately degraded to carbon dioxide and water. The AOPs include:
- Ozonation,
- Fenton and photo-Fenton reactions,
- Photolysis, 
- Semiconductor photocatalysis, and

- Electrochemical processes.

\section{Ozonation}

Ozone is a strong oxidizing agent, capable to react with sulfonamides, either directly or indirectly, through the hydroxyl radicals. The rate and efficiency of sulfonamide degradation during the ozonation process depends on the ozone concentration and $\mathrm{pH}$ value of the sulfonamide solution. During 3 min of ozonation at $\mathrm{pH}=2$ and using $3.2 \mathrm{mg} / \mathrm{dm}^{3}$ of ozone, $92 \%$ of SMX can be degraded [63], while during $1 \mathrm{~min}$ at $\mathrm{pH}=3$ and using 5.5 $\mathrm{mg} / \mathrm{dm}^{3}$ of ozone, more than $99 \%$ of sulfaquinoxaline (SQX) can be degraded [64]. In order to improve ozonation performances, the combination of ozone with UV radiation, hydrogen peroxide or catalysts can be applied.

\section{Fenton and photo-Fenton reactions}

Fenton's reagent represents a solution of hydrogen peroxide and ferrous ions and has a strong oxidative potential [65]. Fenton reaction can take place in homogeneous and heterogeneous systems, although the first system is more often used. In the homogeneous system, the Fenton's reagent represents a solution of hydrogen peroxide and iron salts as a catalyst in the acidic medium [61]. Hydroxyl radicals are formed via a radical mechanism (reaction 1):

$$
\mathrm{Fe}^{2+}+\mathrm{H}_{2} \mathrm{O}_{2} \rightarrow \mathrm{Fe}^{3+}+\mathrm{OH}^{-}+\mathrm{OH}^{*}
$$

In order to increase the efficiency of the oxidation reaction, the combination of Fenton's reagent with UV radiation can be applied, which is referred to as the photoFenton reaction. The UV radiation allows regeneration of $\mathrm{Fe}^{2+}$ ions and further formation of hydroxyl radicals by photolysis of $\mathrm{FeOH}^{2+}$ complex (reaction 2):

$$
\mathrm{FeOH}^{2+} \stackrel{h v}{\longrightarrow} \mathrm{Fe}^{2+}+\mathrm{OH}^{*}
$$

The Fenton reactions efficiency depends on $\mathrm{pH}$, temperature, the presence of the catalyst, the hydrogen peroxide content and the target compound concentration. At the solution $\mathrm{pH}$ less than 3 , the reduction of hydroxyl radicals occurs and significantly affects the Fenton reaction rate. At the solution $\mathrm{pH}=1-2$, hydroxyl radicals react with hydrogen ions forming water molecules. The temperature increase accelerates Fenton reactions. PerezMoya et al. [66] have demonstrated that the total amount of sulfamethazine (SMT) in the solution can be degraded in less than 2 min. However, it is important to note that formed degradation products exhibit greater toxicity to Gram-positive (S. aureus) and Gram-negative (E. coli) bacteria than initial sulfonamide.

\section{Photolysis}

Sulfonamide structures contain an aromatic ring, heteroatoms and other functional chromophore groups, which are susceptible to natural and artificial UV radia- tion. Sulfonamide photodegradation may be caused by absorption of solar radiation (direct photodegradation) or by act of reactive free radicals, such as singlet oxygen, hydroxyl radicals or other reactive species (indirect photodegradation) [67]. The efficiency of sulfonamide photodegradation in the aqueous solution depends on the intensity and frequency of the applied radiation, $\mathrm{pH}$ [68] and water hardness, as well as the presence of photosensitizers [69] such as humic acid and nitrate. The $\mathrm{pH}$ value of the sulfonamide solution affects the degradation rate, but does not affect the type of formed products [70].

Zessel et al. [15] have studied the sulfonamides tendency to degradation under the effect of natural and artificial UV radiation. It has been shown that all investigated sulfonamides undergo photodegradation. Photodegradation has been most pronounced after the sulfonamides exposure to the combined effect of UVA and UVB radiation, then after the UVA radiation and finally after the exposure to sunlight. The degradation rates of various sulfonamides under the same conditions are different. Namely, STZ and SA are almost completely degraded after $4 \mathrm{~h}$ of combined exposure to UVA/UVB radiation, while only $70 \%$ of sulfamethoxypyridazine (SMP) and sulfachloropyridazine (SCP) are degraded after $6 \mathrm{~h}$ under the same conditions. Thus, the tendency to photodegradation depends on the chemical structure of sulfonamides.

Tačić et al. [71] have studied the sulfanilamide photostability, both in aqueous solutions and in the inclusion complexes with $\beta$-cyclodextrin $(\beta C D)$ and 2-hydroxypropyl- $\beta$-cyclodextrin (HP $\beta C D$ ). After 5 min of UVB radiation, $58.12 \%$ of SA was degraded in the solution, while $53.56 \%$ and $42.33 \%$ of SA were degradated in the inclusion complexes of $\beta C D$ and HP $\beta C D$, respectively. The formation of inclusion complexes reduces SA sensitivity toward UV radiation due to sulfanilamide incorporation into cyclodextrin cavities and their protective effects.

Photodegradation of various sulfonamides in the aqueous solution results in different degradation products, including the most common sulfanilic acid, sulfanilamide, aniline, hydroquinone, carboxylic and dicarboxylic acids [72]. The main degradation pathways of sulfonamides and their metabolites include cleavage of S-N bond and the loss of $\mathrm{SO}_{2}$ molecule $[73,74]$. Additionally, hydroxylation of the benzene ring [68] and R-residue bonded to nitrogen of the sulfonamide group [67] are also possible.

As the antimicrobial activity depends on the chemical structure, photodegradation may lead to drug inactivation or the formation of degradation products with a certain antimicrobial activity. Photodegradation products have no cytotoxic potential, except sulfanilamide, and have a minor effect on cell proliferation $[15,75]$.

Semiconductor photocatalysis

Semiconductor photocatalysis requires the presence of 3 basic components: a catalytic photo-sensitive surface (mainly inorganic semiconductor, such as $\mathrm{TiO}_{2}$ ), a 
source of photon energy and a suitable oxidizing agent [75]. The principle involves the semiconductor activation by artificial or natural radiation. The semiconductor photocatalysis mechanism has 5 basic steps: the reactants transfer in the fluid phase to the surface, reactants adsorption, the reaction at the adsorbed phase, products desorption and the product removal from the interface region.

Numerous researches deal with the issue of sulfonamides degradation in the presence of various catalysts, such as $\mathrm{TiO}_{2}$ [75], $\mathrm{FeCl}_{3}$ [76] and the mixtures of catalysts $\mathrm{TiO}_{2} / \mathrm{FeCl}_{3}[76,77]$ and $\mathrm{TiO}_{2} / \mathrm{K}_{2} \mathrm{FeO}_{4}[78]$. Wang et al. [79] have demonstrated that sulfonamide degradation under the effect of visible-light-emitting diodes in the presence of carbon-sensitized and nitrogen-doped $\mathrm{TiO}_{2}\left(\mathrm{C} / \mathrm{N}-\mathrm{TiO}_{2}\right)$ as a catalyst is possible. More than $95 \%$ of sulfanilamide can be degraded by white LED radiation during $5 \mathrm{~h}$, in the presence of $1 \mathrm{~g} / \mathrm{dm}^{3} \mathrm{C} / \mathrm{N}-\mathrm{TiO}_{2}$ calcinated at $300{ }^{\circ} \mathrm{C}$ in acidic medium. The applied catalyst can be re-used 5 times with the efficiency loss of $<10 \%$. Dong et al. [80] have studied the efficiency of sulfanilamide photocatalytic degradation in the presence of bismuth oxychloride/ reduced graphene oxide (BiOCl/RGO) composites as a catalyst. More than $80 \%$ of sulfanilamide degrades in the presence of $0.05 \mathrm{~g}$ of the catalyst, while the optimal initial sulfanilamide concentration is $15 \mathrm{mg} / \mathrm{dm}^{3}$. Sulfanilic acid was identified as the main degradation product.

\section{Electrochemical processes}

Electrochemical processes represent effective, reverse, simple and clean degradation techniques. The oxidation occurs at the anode in the presence of electrolytes. The compounds can be electrochemically degraded directly at the anode, or indirectly in the solution. Haidar et al. [81] have studied the direct electrochemical oxidation of SCP using hydroxyl radicals generated at a boron-doped diamond (BDD) anode. The mineralization rate increases with the increase of the applied voltage, whereby the efficiency exceeds $95 \%$ after $8 \mathrm{~h}$ of treatment at $350 \mathrm{~mA}$. The major SCP oxidation products are 3-amino-6-chloropyridazine and p-benzoquinone. Further degradation results in short-chain aliphatic carboxylic acids such as maleic, oxalic, pyruvic, glyoxylic and malic acid, which possess lower toxicity than SPC and its cyclic intermediates. El-Ghenymy et al. [82] have identified similar degradation products (oxamic, maleic, fumaric, acetic, oxalic and formic acid) in the case of sulfanilamide. Fabianska et al. [83] have monitored the electrochemical degradation efficiency of 5 sulfonamides mixture at the BDD electrode. The degradation efficiency was greater at higher temperatures $\left(60{ }^{\circ} \mathrm{C}\right)$ and in the acidic medium ( $\mathrm{pH}=2$ ). The identification of main degradation products was performed by applying LC-MS and GC-MS techniques, which showed that in most cases S-N bond cleavage and hydroxylation of the aromatic ring occurs.

\section{lonizing radiation}

In addition to all above mentioned AOPs, ionizing radiation at the dose of $0.6 \mathrm{kGy}$ can be also applied for sulfonamides degradation [60]. Sulfonamide degradation begins with the hydroxyl radical addition to a benzene ring resulting in the cyclohexadienyl radical. The formed radical reacts with dissolved oxygen and converts into the peroxy radical. The phenol formation, ring opening and fragmentation occur simultaneously. Hydroxylated molecules, which are primary degradation products, retained the aromatic structure and reacted with hydroxyl radicals at the same rate as parental sulfonamides. Dihydroxy-sulfonamide derivatives are formed by further oxidation. The complete sulfonamides degradation, also called mineralization, includes the formation of inorganic molecules and ions, such as $\mathrm{H}_{2} \mathrm{O}, \mathrm{CO}_{2}, \mathrm{SO}_{4}{ }^{2-}, \mathrm{NH}_{4}{ }^{+}$and $\mathrm{NO}_{3}^{-}$.

In Figure 7, free-radical degradation is schematically presented in case of sulfanilamide.

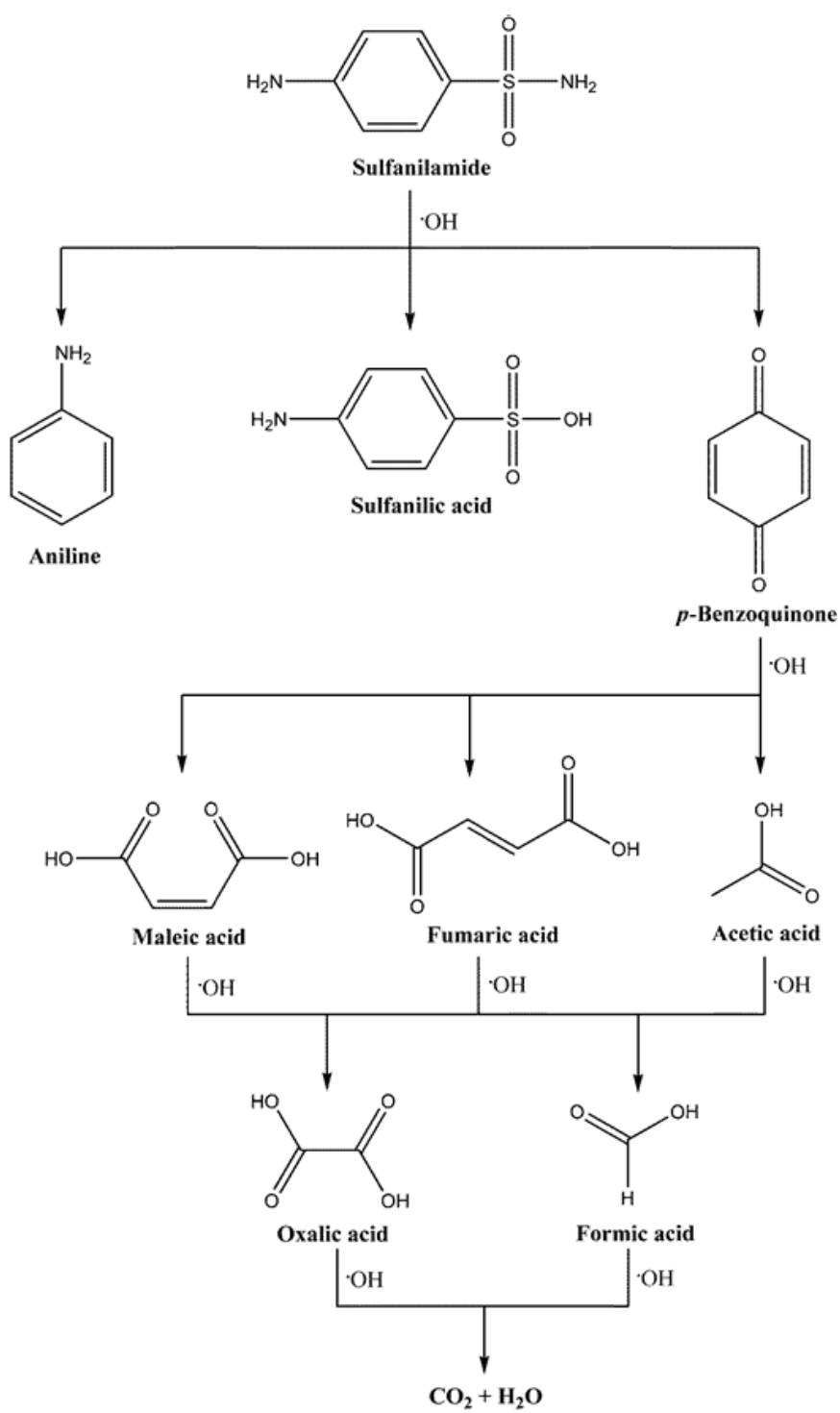

Figure 7. Schematic representation of sulfanilamide free radical degradation 
Adsorption and membrane processes

Although the adsorption is a well-known process, in recent years its application in the sulfonamides removal from the environment has been limited. However, several substances such as coal and coconut based powdered activated carbon [84], multiwalled carbon nanotubes [85], zeolite $Y$ [86] and porous polymeric resins [87] can be used as effective adsorbents for the sulfonamides removal. Membrane processes are used for the sulfonamides separation in which there is no degradation, but only transfer to a new phase (membrane) and the concentration of sulfonamides. Membrane processes used for the sulfonamides removal from different samples are: reverse osmosis [62], nanofiltration [88], ultrafilatration [89] and ion exchange [62,90].

In order to improve the performances of techniques applied for the degradation and/or removal of active substances from the environment, the methods that represent the combination of some of the described processes tend to be used. Although the combined methods are not often used, they are the most powerful methods for the removal of different antimicrobial substances from the environment [61].

\section{Hydrolysis}

Hydrolysis is another important way of antimicrobial substances degradation outside the human body. Literature about hydrolytic stability of sulfonamides shows that most of sulfonamides are hydrolytically stable, under normal $\mathrm{pH}$ and temperature conditions, and retain in the environment for the long period of time. However, sulfonamides are sensitive to hydrolysis in acidic solutions [44]. In the acidic medium ( $\mathrm{pH}=4)$ and at the temperature of $70{ }^{\circ} \mathrm{C}$, sulfanilic acid, sulfanilamide and aniline are the main degradation products of SXZ, SDM, SMP and SCP [91].

\section{Biodegradation}

Biodegradation involves the sulfonamides decomposition under the effect of bacteria, fungi or enzymes. The information about biodegradation of different sulfonamide drugs is controversial. The studies have shown that sulfonamides are not the subject to biodegradation under aerobic and anaerobic conditions, nor in aqueous solutions, while their degradation products are biodegradable [15,75]. Zhang et al. [92] have shown that both biotic and abiotic factors play a significant role in SMX, SMT and SDM degradation in the lake waters and sediments. Additionally, Yang et al. [93] have concluded that microbial degradation represents the main removal method of the aforementioned sulfonamides from the sludge. The addition of spent mushroom compost which contains enzymes, bacteria and fungi, accelerates the sulfonamides degradation 6 times. The main bacterial strains involved in the sulfonamides degradation in the sludge are Acinetobacter and Pseudomonas species.

For the detection and identification of different sulfonamides and their metabolites in the waste water, sludge and soil samples, chromatography techniques in the combination with mass spectrometry, in particular LC-MS/MS [94,95], UHPLC-MS/MS [64,96], GC/MS [85] and HPLC [62] among others, are most commonly used.

\section{Conclusion}

Sulfonamide antimicrobial drugs represent an important class of synthetic substances with different physico chemical, pharmacokinetic and pharmacodynamic characteristics. Sulfonamides are used in the therapy of urogenital, gastrointestinal and respiratory tract infections, then for the eye, skin and mucous membrane infections, as well as in the prevention and treatment of burn infections. The sulfonamides application in the therapy is partially limited by the bacterial resistance and sulfonamides side effects. In order to overcome the resistance and to reduce the adverse effects, continuous efforts are made to synthesize novel antimicrobial compounds with the sulfonamide structure and to develop novel formulations with the existing sulfonamide substances. On the other side, the sulfonamides application in therapy leads to their introduction into the environment and maintaining the resistance. The environmental fate of sulfonamides depends on the influence of various biotic and abiotic factors such as the presence of some degrading bacteria and fungi, temperature, $\mathrm{pH}$, and UV radiation. Additionally, numerous techniques can be applied in order to degrade and remove present sulfonamides from different compartments of the environment. Sulfonamides degradation leads to the formation of less active and toxic compounds, and in the end, carbon dioxide and water. In that way, the sulfonamides presence in the environment can be limited.

\section{Acknowledgements}

This work is a part of the research project "Plant and synthetic bioactive products of new generation" No. TR34012, financed by the Ministry of Education, Science and Technological Development of the Republic of Serbia.

Abbreviations and symbols

PABA - p-Aminobenzoic acid

SAM - Sulfacetamide sodium

SCP - Sulfachloropyridazine

SDM - Sulfadimethoxine

SDZ - Sulfadiazine

SGV - Sulfaguanidine

SFL - Sulfalene

SLZ - Sulfasalazine

SML - Sulfametrole

SMP - Sulfamethoxypyridazine

SMT - Sulfamethazine

SMX - Sulfamethoxazole

SMZ - Sulfamerazine

SQX - Sulfaquinoxaline

STZ - Sulfathiazole 
TMP - Trimethoprim

\section{References}

[1] N. Anand, in Mechanism of Action of Antimicrobial and Antitumor Agents vol. 3, J. W. Corcoran, F. E. Hahn, J. F. Snell, K. L. Arora Eds., Springer, Berlin, Heidelberg 1975, p. 668-698.

[2] "The Nobel Prize in Physiology or Medicine 1939". Nobelprize.org. Nobel Media AB 2014. Web. 5 Apr 2017. http://www.nobelprize.org/nobel_prizes/medicine/ laureates/1939/

[3] J. R. Fouts, J. J. Kamm, B. B. Enzymatic reduction of prontosil and other azo dyes, Journal of Pharmacology and Experimental Therapeutics 120(3) (1957) 291-300.

[4] H. C. Neu, T. D. Gootz, in Medical Microbiology, S. Baron Ed., The University of Texas Medical Branch at Galveston, Galveston 1996.

[5] K. C. Van Meter, R. J. Hubert, Microbiology for the Healthcare Professional, Elsevier, China, 2016, p. 214232.

[6] V. M. Varagić, M. P. Milošević, Farmakologija, Elitmedica, Beograd, 2009, p. 622-627.

[7] T. Struller, in Antibiotics and Chemotherapy, O. Gsell Ed., Karger, Basel 1968, p. 179-215.

[8] S. Budavari, The Merck index: an encyclopedia of chemicals, drugs, and biologicals, Merck and Co. Inc, Rahway, NJ, 1989, p. 1409.

[9] D. Cairns, Essentials of Pharmaceutical Chemistry, Third edition, Pharmaceutical Press, London, Chicago, 2008, p. 69.

[10] A. Kolaczek, I. Fusiarz, J. Lawecka, D. Branowska, Biological activity and synthesis of sulfonamide derivatives: a brief review, Chemik, 68(7) (2014) 620-628.

[11] K. Bahrami, M. M. Khodaei, M. Soheilizad, Direct Conversion of Thiols to Sulfonyl Chlorides and Sulfonamides, The Journal of Organic Chemistry, 74 (2009) 9287-9291.

[12] K. L. Williamson, K. M. Masters, Macroscale and microscale organic experiments, Brooks/Cole, Cengage Learning, Australia, Brazil, Japan, Korea, Mexico, Singapore, Spain, United Kingdom, United States, 2011, p. $565-588$.

[13] D. L. Pavia, G. M. Lampman, G. S. Kriz, R. G. Engel, Introduction to organic laboratory techniques: A smallscale approach, Brooks/Cole, a division of Thomson Learning, Inc. Canada, 2011, p. 363-370.

[14] M. A. Miller-Hjelle, V. Somaraju, J. T. Hjelle, in Modern Pharmacology with Clinical Applications, C. R. Craig, R. E. Stitzel Ed., Lippincott Williams \& Wilkins, Philadelphia, Baltimore, New York, London, Buenos Aires, Hong Kong, Sydney, Tokyo 2004, p. 515-525.

[15] K. Zessel, S. Mohring, G. Hamscher, M. Kietzmann, J. Stahl, Biocompatibility and antibacterial activity of photolytic products of sulfonamides, Chemosphere, 100 (2014) 167-174.

[16] R. J. Henry, The mode of action of sulfonamides, Bacteriological Reviews, 7(4) (1943) 175-262.

[17] G. M. Brown, The biosynthesis of folic acid: II. Inhibition by sulfonamides, The Journal of Biological Chemistry, 237 (1962) 536-540.

[18] A. Ronald, The etiology of urinary tract infection: traditional and emerging pathogens, Disease-a-Month, 49(2) (2003) $71-82$.
[19] J. M. McCarthy, G. Richard, W. Huck, R. M. Tucker, R. L. Tosiello, M. Shan, A. Heyd, R. M. Echols, A randomized trial of short-course ciprofloxacin, ofloxacin, or trimethoprim/ sulfamethoxazole for the treatment of acute urinary tract infection in women. Ciprofloxacin urine tract infection group, The American Journal of Medicine, 106 (1999) 292-299.

[20] P. Franks, J. A. Gleiner, The treatment of acute bronchitis with trimethoprim and sulfamethoxazole, The Journal of Family Practice, 19 (1984) 185-190.

[21] E. Kurzer, S. A. Kaplan, Cost effectiveness model comparing trimethoprim sulfamethoxazole and ciprofloxacin for the treatment of chronic bacterial prostatitis, European Urology, 42 (2002) 163-166.

[22] Y. Sakiyama, N. Kanda, Y. Higuchi, M. Yoshimura, H. Wakaguri, Y. Takata, O. Watanabe, J. Yuan, Y. Tashiro, R. Saigo, S. Nozuma, A. Yoshimura, S. Arishima, K. Ikeda, K. Shinohara, H. Arata, K. Michizono, K. Higashi, A. Hashiguchi, Y. Okamoto, R. Hirano, T. Shiraishi, E. Matsuura, R. Okubo, I. Higuchi, M. Goto, H. Hirano, A Sano, T. Iwasaki, F. Matsuda, S. Izumo, H. Takashima, New type of encephalomyelitis responsive to trimethoprim/ sulfamethoxazole treatment in Japan, Neurology: Neuroimmunology \& Neuroinflammation, 2(5) (2015) e143.

[23] A. Yazici, P. C. Ozdal, I. Taskintuna, S. Kavuncu, G. Koklu, Trimethoprim/sulfamethoxazole and azithromycin combination therapy for ocular toxoplasmosis, Ocular Immunology and Inflammation, 17(4) (2009) 289-291.

[24] Z. Berkani, Y. Kitouni, A. Lakehal, D. Roula, Trimethoprim/ sulfamethoxazole and azithromycin combination in the treatment of presumed ocular toxoplasmosis, Investigative Ophthalmology \& Visual Science, 56 (2015) 1894.

[25] A. Vena, M. Falcone, E. Comandini, M. Meledandri, A. Novelli, F. Campanile, S. Stefani, M. Venditi, Daptomycin plus trimethoprim/sulfamethoxazole combination therapy in post-neurosurgical meningitis caused by linezolidresistant Staphylococcus epidermidis, Diagnostic Microbiology and Infectious Disease, 76(1) (2013) 99-102.

[26] D. M. Livermore, S. Mushtaq, M. Wamer, N. Woodford, Comparative in vitro activity of sulfametrole/trimethoprim and sulfamethoxazole/trimethoprim and other agents against multiresistant Gram-negative bacteria, Journal of Antimicrobial Chemotherapy, 69 (2014) 1050-1056.

[27] T. B. Vree, E. Schoondermark-van de Ven, C. P. W. G. M. Vervey-van Wissen, A. M. Baars, A. Swolfs, P. M. van Galen, H. Amatdjais-Groenen, Isolation, identification and determination of sulfadiazine and its hydroxy metabolites and conjugates from man and Rhesus monkey by high-performance liquid chromatography, Journal of Chromatography B, 670 (1995) 111-123.

[28] M. Soheilian, M. Sadoughi, M. Ghajarnia, M. H. Dehghan, S. Yazdani, H. Behboudi, A. Anisian, G. A. Peyman, Prospective randomized trial of trimethoprim/ sulfamethoxazole versus pyrimethamine and sulfadiazine in the treatment of ocular toxoplasmosis, Ophthalmology, 112(11) (2005) 1876-1882.

[29] M. A. Gerber, R. S. Baltimore, C. B. Eaton, M. Gewitz, K. A. Taubert, Prevention of rheumatic fever and diagnosis and treatment of acute streptococcal pharyngitis, Circulation, 119 (2009) 1541-1551.

[30] R. W. Snyder, D. B. Glasser, Antibiotic Therapy for Ocular Infection, Western Journal of Medicine, 161 (1994) 579584. 
[31] D. Sensoy, E. Cevher, A. Sarici, M. Yilmaz, A. Ozdamar, N. Bergisadi, Bioadhesive sulfacetamide sodium microspheres: Evaluation of their effectiveness in the treatment of bacterial keratitis caused by Staphylococcus aureus and Pseudomonas aeruginosa in a rabbit model, European Journal of Pharmaceutics and Biopharmaceutics, 72 (2009) 487-495.

[32] J. Q. Del Rosso, The use of sodium sulfacetamide $10 \%$-sulfur $5 \%$ emollient foam in the treatment of acne vulgaris, The Journal of Clinical and Aesthetic Dermatology, 2(8) (2009) 26-29.

[33] M. W. Trumbore, J. A. Goldstein, R. M. Gurge, Treatment of papulopustular rosacea with sodium sulfacetamide $10 \% /$ sulfur $5 \%$ emollient foam, Journal of Drugs in Dermatology, 8(3) (2009) 299-304.

[34] H. J. Klasen, A historical review of the use of silver in the treatment of burns. II. Renewed interest for silver, Burns, 26 (2000) 131-138.

[35] O. Sköld, in Antimicrobial Drug Resistance, D. L. Mayers Ed., Humana Press, Dordrecht, Heidelberg, London, New York2009, pp. 259-269.

[36] R. G. Finch, D. Greenwood, S. R. Norrby, R. J. Whitley, Antibiotic and Chemotherapy, Saunders Elsevier, Edinburgh, London, New York, Philadelphia, St Louis, Sydney, Toronto, 2010, p. 337.

[37] L. A. Rantz, W. M. M. Kirby, The use of sulfaguanidine in the treatment of dysentery carriers, JAMA, 118(15) (1942) 1268-1271.

[38] R. Seishima, K. Okabayashi, O. Nagano, H. Hasegawa, M. Tsuruta, M. Shimoda, K. Kameyama, H. Saya, Y. Kitagawa, Sulfasalazine, a therapeutic agent for ulcerative colitis, inhibits the growth of CD44v9(+) cancer stem cells in ulcerative colitis-related cancer, Clinics and Research in Hepatology and Gastroenterology, 40(4) (2016) 487-493.

[39] E. Strauss, F. C. Lowell, F. H. Laskey Taylor, M. Finland, Observations on the apsorption, excretion and distribution of sulfanilamide, sulfapyridine, sulfathiazole and sulfamethylthiazole, Annals of Internal Medicine, 14(8) (1941) 1360-1382.

[40] B. D. Davis, The binding of sulfonamide drugs by plasma proteins. A factor in determining the distribution of drugs in the body, The Journal of Clinical Investigation, 22(5) (1943) 753-762.

[41] T.B. Vree , J.B. Vree , E.W.J. Beneken Kolmer, Y.A. Hekster, Novel oxidative pathways of sulphapyridine and sulphadiazine by the turtle Pseudemys scriptaelegans, Veterinary Quarterly, 13(4) (1991) 218-224.

[42] J. F. M. Nouws, T. B. Vree, Y. A. Hekster, In vitro antimicrobial activity of hydroxy and $\mathrm{N}_{4}$-acetyl sulphonamide metabolites, Veterinary Quarterly, 7(1) (1985) 70-72.

[43] A. S. Kalgutkar, R. Jones, A. Sawant, in Metabolism, Pharmacokinetics and Toxicity of Functional Groups: Impact of Chemical Building Blocks on ADMET, D. A. Smith Ed., Royal Society of Chemistry, Cambridge 2010, p. 210.

[44] P. Sukul, M. Spiteller, Sulfonamides in the environment as veterinary drugs, Reviews of Environmental Contamination and Toxicology, 187 (2006) 67-101.

[45] R. S. Gruchalla, Diagnosis of allergic reactions to sulfonamides, Allergy, 54 (1999) 28-32.

[46] C. C. Brackett, H. Singh, J. H. Block, Likelihood and mechanisms of cross-allergenicity between sulfonamide antibiotics and other drugs containing a sulfonamide functional group, Pharmacotherapy, 24(7) (2004) 856-870.

[47] G. Choquet-Kastylevsky, T. Vial, J. Descotes, Allergic adverse reactions to sulfonamides, Current Allergy and Asthma Reports, 2(1) (2002) 16-25.

[48] S. R. Knowles, L. E. Shapiro, N. H. Shear, Reactive Metabolites and Adverse Drug Reactions, Clinical Reviews in Allergy and Immunology, 24 (2003) 229-238.

[49] M. J. Rieder, N. H. Shear, A. Kanee, B. K. Tang, S. P. Spielberg, Prominence of slow acetylator phenotype among patients with sulfonamide hypersensitivity reactions, Clinical Pharmacology \& Therapeutics, 49(1) (1991) 13-17.

[50] L. E. Shapiro, S. R. Knowles, E. Weber, M. G. Neuman, N. H. Shear, Safety of celecoxib in individuals allergic to sulfonamide. A pilot study, Drug Safety, 26(3) (2003) 187 195.

[51] B. L. Strom, R. Schinnar, A. J. Apter, D. J. Margolis, E. Lautenbach, S. Hennessy, W. B. Bilker, D. Pettitt, Absence of Cross-Reactivity between Sulfonamide Antibiotics and Sulfonamide Nonantibiotics, The New England Journal of Medicine, 349(17) (2003)1628-1635.

[52] G. C. Wall, J. E. DeWitt, S. Haack, A. Fornoff, D. K. Eastman, C. F. Koenigsfeld, Knowledge and attitudes of American pharmacists concerning sulfonamide allergy cross-reactivity, Pharmacy World \& Science, 32 (2010) 343-346.

[53] M. J. Rieder, J. Uetrecht, N. H. Shear, M. Cannon, M. Miller, S. P. Spielberg, Diagnosis of Sulfonamide Hypersensitivity Reactions by In-Vitro "Rechallenge" with Hydroxylamine Metabolites, Annals of Internal Medicine, 110(4) (1989) 286-289.

[54] F. C. Tenover, Mechanisms of antimicrobial resistance in bacteria, The American Journal of Medicine, 119(6) (2006) 3-10.

[55] O. Skold, Resistance to trimethoprim and sulfonamides, Veterinary Research, 32 (2001) 261-273.

[56] W. Buwembo, S. Aery, C. M. Rwenyonyi, G. Swedberg, F. Kironde, Point mutations in the folP gene partly explain sulfonamide resistance of Streptococcus mutans, International Journal of Microbiology, 2013 (2013) 1-6.

[57] P. Huovinen, L. Sundstrom, G. Swedberg, O. Skold, Trimethoprim and sulfonamide resistance, Antimicrobial Agents and Chemotherapy, 39(2) (1995) 279-289.

[58] Y. Deng, X. Bao, L. Ji, L. Chen, J. Liu, J. Miao, D. Chen, H. Bian, Y. Li, G. Yu, Resistance integrons: class 1, 2 and 3 integrons, Annals of Clinical Microbiology and Antimicrobials, 14(45) (2015) 1-11.

[59] P. Radstrom, G. Swedberg, O. Skold, Genetic analyses of sulfonamide resistance and its dissemination in gramnegative bacteria illustrate new aspects of $\mathrm{R}$ plasmid evolution, Antimicrobial Agents and Chemotherapy, 35 (1991) 1840-1848.

[60] G. Sagi, T. Csay, L. Szabo, G. Patzay, E. Csonka, E. Takacs, L. Wojnarovits, Analytical approaches to the $\mathrm{OH}$ radical induced degradation of sulfonamide antibiotics in dilute aqueous solutions, Journal of Pharmaceutical and Biomedical Analysis, 106 (2015) 52-60.

[61] V. Homem, L. Santos, Degradation and removal methods of antibiotics from aqueous matrices - A review, Journal of Environmental Management, 92 (2011) 2304-2347.

[62] C. Adams, Y. Wang, K. Loftin, M. Meyer, Removal of antibiotics from surface and distilled water in conventional water treatment processes, Journal of Environmental Engineering, 128(3) (2002) 253-260. 
[63] T. Garoma, S. K. Umamaheshwar, A. Mumper, Removal of sulfadiazine, sulfamethizole, sulfamethoxazole, and sulfathiazole from aqueous solution by ozonation, Chemosphere 79 (2010) 814-820.

[64] V. R. Urbano, M. G. Maniero, M. Perez-Moya, J. R. Guimaraes, Influence of $\mathrm{pH}$ and ozone dose on sulfaquinoxaline ozonation, Journal of Environmental Management, xxx (2016) 1-8.

[65] S. Gan, E. V. Lau, H. K. Ng, Remediation of soils contaminated with polycyclic aromatic hydrocarbons (PAHs), Journal of Hazardous Materials, 172 (2-3) (2009) 532-549.

[66] M. Perez-Moya, M. Graells, G. Castells, J. Amigo, E. Ortega, G. Buhigas, L. M. Perez, H. D. Mansilla, Characterization of the degradation performance of the sulfamethazine antibiotic by photo-Fenton process, Water Research, 44 (2010) 2533-2540.

[67] M. W. Lam, S. A. Mabury, Photodegradation of the pharmaceuticals atorvastatin, carbamazepine, levofloxacin, and sulfamethoxazole in natural waters, Aquatic Sciences, 67 (2005) 177-188.

[68] A. G. Trovo, R. F. P. Nogueira, A. Aguera, C. Sirtori, A. R. Fernandez-Alba, Photodegradation of sulfamethoxazole in various aqueous media: Persistence, toxicity and photoproducts assessment, Chemosphere 77 (2009) 1292-1298.

[69] R. Andreozzi, M. Raffaele, P. Nicklas, Pharmaceuticals in STP effluents and their solar photodegradation in aquatic environment, Chemosphere, 50 (2003) 1319-1330.

[70] A. L. Boreen, W. A. Arnold, K. McNeill, Photochemical fate of sulfa drugs in the aquatic environment: sulfa drugs containing five-membered heterocyclic groups, Environmental Science \& Technology, 38(14) (2004) 3933-3940.

[71] A. Tačić, I. Savić, V. Nikolić, I. Savić, S. Ilić-Stojanović, D. Ilić, S. Petrović, M. Popsavin, A. Kapor, Inclusion complexes of sulfanilamide with $\beta$-cyclodextrin and 2-hydroxypropyl- $\beta$-cyclodextrin, Journal of Inclusion Phenomena and Macrocyclic Chemistry, 80(1) (2014) 113-124.

[72] M. J. Garsia-Galan, M. S. Diaz-Cruz, D. Barcelo, Identification and determination of metabolites and degradation products of sulfonamide antibiotics, Trends in Analytical Chemistry, 27(11)(2008) 1008-1022.

[73] M. Periša, S. Babić, I. Škorić, T. Fromel, T. P. Knepper, Photodegradation of sulfonamides and their N4acetylatedmetabolites in water by simulated sunlight irradiation: kinetics and identification of photoproducts, Environmental Science and Pollution Research, 20 (2013) 8934-8946.

[74] A. Borba, A. Gomez-Zavaglia, R. Fausto, Conformational landscape, photochemistry, and infrared spectra of sulfanilamide, The Journal of Physical Chemistry A, 117(4) (2013) 704-717.

[75] W. Baran, J. Sochacka, W. Wardas, Toxicity and biodegradability of sulfonamides and products of their photocatalytic degradation in aqueous solutions, Chemosphere 65 (2006) 1295-1299.

[76] W. Baran, E. Adamek, A. Sobczak, J. Sochacka, The comparison of photocatalytic activity of Fe-salts, $\mathrm{TiO}_{2}$ and $\mathrm{TiO}_{2} / \mathrm{FeCl}_{3}$ during the sulfanilamide degradation process, Catalysis Communications, 10 (2009) 811-814.

[77] J. Ziemianska, E. Adamek, A. Sobczak, I. Lipska, A. Makowski, W. Baran, The study of photocatalytic degradation of sulfonamides applied to municipal wastewater, Physicochemical Problems of Mineral Processing, 45 (2010) 127-140.

[78] Y. Ma, K. Zhang, C. Li, T. Zhang, N. Gao, Oxidation of sulfonamides in aqueous solution by $\mathrm{UV}-\mathrm{TiO}_{2}-\mathrm{Fe}(\mathrm{VI})$ BioMed Research International, 2015 (2015) 1-10.

[79] P. Wang, T. Zhou, R. Wang, T. T. Lim, Carbon-sensitized and nitrogen-doped $\mathrm{TiO} 2$ for photocatalytic degradation of sulfanilamide under visible-light irradiation, Water Research, 45 (2011) 5015-5026.

[80] S. Dong, Y. Pi, Q. Li, L. Hu, Y. Li, X. Han, J. Wang, J. Sun, Solar photocatalytic degradation of sulfanilamide by $\mathrm{BiOCl} /$ reduced graphene oxide nanocomposites: Mechanism and degradation pathways, Journal of Alloys and Compounds, 663 (2016) 1-9.

[81] M. Haidar, A. Dirany, I. Sires, N. Oturan, M. A. Oturan, Electrochemical degradation of the antibiotic sulfachloropyridazine by hydroxyl radicals generated at a BDD anode, Chemosphere, 91 (2013) 1304-1309.

[82] A. El-Ghenymy, J. A. Garrido, R. M. Rodríguez, P. L. Cabot, F. Centellas, C. Arias, E. Brillas, Degradation of sulfanilamide in acidic medium by anodic oxidation with a boron-doped diamond anode, Journal of Electroanalytical Chemistry, 689 (2013) 149-157.

[83] A. Fabianska, A. Bialk-Bielinska, P. Stepnowski, S. Stolte, E. M. Siedlecka, Electrochemical degradation of sulfonamides at BDD electrode: Kinetics, reaction pathway and eco-toxicity evaluation, Journal of Hazardous Materials, 280 (2014) 579-587.

[84] K. J. Choi, S. G. Kim, S. H. Kim, Removal of tetracycline and sulfonamide classes of antibiotic compound by powdered activated carbon, Environmental Technology, 29(3) (2008) 333-342.

[85] L. Ji, W. Chen, S. Zheng, Z. Xu, D. Zhu, Adsorption of sulfonamide antibiotics to multiwalled carbon nanotubes, Langmuir, 25(19) (2009) 11608-11613.

[86] I. Braschi, S. Blasioli, L. Gigli, C. E. Gessa, A. Alberti, A. Martucci, Removal of sulfonamide antibiotics from water: Evidence of adsorption into an organophilic zeolite $Y$ by its structural modifications, Journal of Hazardous Materials, 178 (2010) 218-225.

[87] W. Yang, F. Zheng, X. Xue, Y. Lu, Investigation into adsorption mechanisms of sulfonamides onto porous adsorbents, Journal of Colloid and Interface Science, 362(2)(2011) 503-509.

[88] M. R. Ramli, N. Meriam, N. Sulaiman, M. A. Mohd, M. F. Rabuni, Performance of chlorination process during nanofiltration of sulfonamide antibiotic, Water Science and Technology, 72(9) (2015) 1611-1620.

[89] K. Exall, V. K. Balakrishnan, J. Toito, R. McFadyen, Impact of selected wastewater constituents on the removal of sulfonamide antibiotics via ultrafiltration and micellar enhanced ultrafiltration, Science of the Total Environment, 461-462 (2013) 371-376.

[90] K. J. Choi, H. J. Son, S. H. Kim, lonic treatment for removal of sulfonamide and tetracycline classes of antibiotic, Science of The Total Environment, 387 (1-3) (2007) 247-256.

[91] A. Bialk-Bielinska, S. Stolte, M. Matzke, A. Fabianska, J. Maszkowska, M. Kolodziejska, B. Liberek, P. Stenowski, J. Kumirska, Hydrolysis of sulphonamides in aqueous solutions, Journal of Hazardous Materials, 221-222 (2012) 264-274.

[92] Y. Zhang, J. Xu, Z. Zhong, C. Guo, L. Li, Y. He, W. Fan, 
Y. Chen, Degradation of sulfonamides antibiotics in lake water and sediment, Environmental Science and Pollution Research, 20 (2013) 2372-2380.

[93] C. W. Yang, W. C. Hsiao, B. V. Chang, Biodegradation of sulfonamide antibiotics in sludge, Chemosphere, 150 (2016) 559-565.

[94] N. Le-Minh, R. M. Stuetz, S. J. Khan, Determination of six sulfonamide antibiotics, two metabolites and trimethoprim in wastewater by isotope dilution liquid chromatography/ tandem mass spectrometry, Talanta, 89 (2012) 407-416.
[95] O. Koba, O. Golovko, R. Kodešova, M. Fer, R. Grabic, Antibiotics degradation in soil: A case of clindamycin, trimethoprim, sulfamethoxazole and their transformation products, Environmental Pollution, 220 (2017) 1251-1263.

[96] X. Yuan, Z. Qiang, W. Ben, B. Zhu, J. Liu, Rapid detection of multiple class pharmaceuticals in both municipal wastewater and sludge with ultra high performance liquid chromatography tandem mass spectrometry, Journal of Environmental Sciences, 26 (2014) 1949-1959.

\section{Izvod}

\section{ANTIMIKROBNI SULFONAMIDNI LEKOVI}

Ana Tačić, Vesna Nikolić, Ljubiša Nikolić, Ivan Savić

Tehnološki fakultet, Leskovac, Srbija

Sulfonamidi su prvi uspešno sintetisani antimikrobni lekovi. Mehanizam antimikrobnog delovanja sulfonamida uključuje kompetetivnu inhibiciju sinteze folne kiseline, čime se sprečava rast i razmnožavanje mikroorganizama. Usled ovakvog mehanizma delovanja, sulfonamidi pripadaju grupi bakteriostatika. lako se primenjuju već više od 70 godina, i dalje postoje stanja i bolesti za čiju terapiju su sulfonamidi lekovi prvog izbora. Šira primena sulfonamida ograničena je bakterijskom rezistencijom i neželjenim efektima sulfonamida. Sulfonamidi i njihovi metaboliti se svrstavaju u grupu perzistentnih organskih zagađivača. Degradacija i uklanjanje sulfonamida iz životne sredine se može postići primenom različitih tehnika, kao što su oksidacione tehnike, u koje spadaju hlorovanje i napredni oksidacioni procesi, zatim adsorpcioni i membranski procesi, kao i kombinovani procesi.
(PREGLEDNI RAD)

UDK 547.521:615.33:66.09

Ključne reči: sulfonamidi, antimikrobna aktivnost, mehanizam delovanja, sinteza, neželjeni efekti, degradacija. 